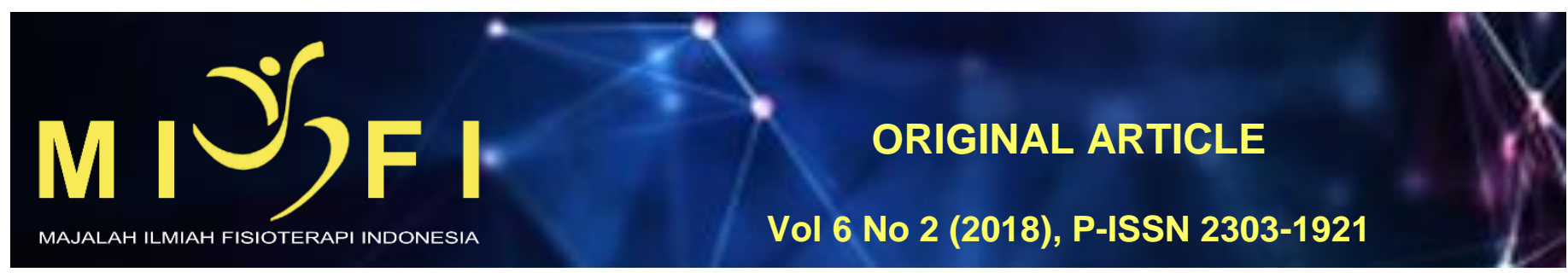

\author{
INTEGRATED NEUROMUSCULAR INHIBITION TECHNIQUE \\ LEBIH MENINGKATKAN LINGKUP GERAK SENDI LEHER \\ DARIPADA CONTRACT RELAX STRETCHING \\ PADA KASUS SINDROM MYOFASCIAL OTOT UPPER TRAPEZIUS
}

\author{
Putu Ayu Sita Saraswati ${ }^{1}$, Ni Komang Juni Antari ${ }^{2}$, Anak Agung Gede Angga Puspa Negara ${ }^{3}$ \\ ${ }^{1,2,3}$ Program Studi Fisioterapi, Universitas Udayana Denpasar Bali \\ sitasaras@gmail.com
}

\begin{abstract}
ABSTRAK
Sindrom myofascial pada otot upper trapezius merupakan nyeri otot yang ditandai oleh satu atau beberapa myofascial trigger point pada otot upper trapezius. Posisi kerja statis dalam jangka waktu lama memicu timbulnya masalah tersebut dan mengakibatkan nyeri dan keterbatasan gerak pada leher sehingga akan menimbulkan disabilitas leher. Penanganan fisioterapi berupa integrated neuromuscular inhibition technique (INIT) dan contract relax stretching yang dikombinasikan dengan modalitas ultrasound berdampak pada penurunan disabilitas leher. Mengetahui metode yang lebih efektif dalam meningkatkan lingkup gerak sendi leher pada sindrom myofascial otot upper trapezius. Jenis penelitian eksperimental dengan rancangan randomized pre test and post test group design. Sampel sebanyak 24 orang dibagi menjadi dua kelompok masing-masing 12 orang secara random. Kelompok perlakuan 1 dengan kombinasi INIT dengan ultrasound, sedangkan perlakuan 2 dengan contract relax stretching dengan ultrasound. Data diperoleh dengan mengukur lingkup gerak sendi leher (LGS) saat lateral fleksi dengan goniometer pada saat sebelum dan setelah perlakuan. Diperoleh peningkatan LGS $5,083 \pm 1,084^{\circ}(p<0,001)$ pada Kelompok 1 dan peningkatan LGS $3,333 \pm 0,778^{\circ}$ $(p<0,001)$ pada kelompok 2 . Hal ini berarti bahwa dalam setiap kelompok terjadi peningkatan lingkup gerak sendi leher secara bermakna. Hasil uji antar kelompok menunjukkan terdapat perbedaan yang bermakna pada peningkatan LGS $(p<0,001)$. Penambahan INIT lebih meningkatkan lingkup gerak sendi leher daripada contract relax stretching pada kasus sindrom myofascial otot upper trapezius
\end{abstract}

Kata kunci : myofascial, trapezius, INIT, ultrasound, stretching, lingkup gerak sendi leher

\title{
COMBINATION OF INTEGRATED NEUROMUSCULAR INHIBITION TECHNIQUE IS MORE EFFECTIVE THAN CONTRACT RELAX STRETCHING TO ULTRASOUND MODALITY IN INCREASING NECK RANGE OF MOTION OF MYOFASCIAL SYNDROME IN UPPER TRAPEZIUS MUSCLE
}

\begin{abstract}
Myofascial pain syndrome in upper trapezius muscle is a muscle pain that implicated by one or some myofascial trigger points in upper trapezius muscle. Working with static position in long time stimulating the presence of myofascial trigger points that causing pain and movement limitation of the neck that stimulate neck disability. Physical therapy's intervention for reducing pain in this case could be integrated neuromuscular inhibition technique or contract relax stretching combined with ultrasound modality. To compare the both interventions in reducing neck disability of myofascial pain syndrome in upper trapezius muscle. This was an experimental study with Randomized Pre and Post Test Group Design. Samples were divided into 2 treatment group that consist 12 samples for each group. The first group treated with integrated neuromuscular inhibition technique with ultrasound while the second group treated with contract relaxes stretching with ultrasound. The data was collected by measuring neck range of motion using goniometer at the time before and after treatment. The $1^{\text {st }}$ group showed that the Neck ROM increase $5.083 \pm 1.084^{\circ}(p<0.001)$ and the $2^{\text {nd }}$ group showed that the Neck ROM increase $3.333 \pm 0.778^{\circ}(p<0.001)$. It means there were significant effect of each treatment in both groups. The results of independent $t$-test showed $p<0.001$, so that there was significant difference of increased Neck ROM between these groups. The result of independent t-test showed $p$ value 0.001 , so there was significant difference between two groups at increasing neck ROM. Combination integrated neuromuscular inhibition technique is more effective than contract relax stretching to ultrasound modality in increasing neck range of motion of myofascial syndrome in upper trapezius muscle.
\end{abstract}

Keywords: myofascial, neck disability, trapezius, INIT, ultrasound, stretching 


\section{PENDAHULUAN}

Beraktivitas dalam posisi statis dalam jangka waktu yang lama dengan pola yang tidak ergonomis akan menimbulkan dampak seperti nyeri otot dan keterbatasan gerak salah satunya pada daerah leher dan bahu. Studi menunjukkan prevalensi nyeri musculoscletal pada leher di Indonesia selama 1 tahun sebesar $40 \%$ dan prevalensi ini lebih tinggi pada wanita1. Prevalensi dan kondisi sindrom myofascial khususnya daerah leher dan bahu di SMPN 2 Adiwerna Kabupaten Tegal terhadap 62 pegawai tata usaha dan guru pengajar ditemukan hasil $30 \%$ mengalami sindrom myofascial otot Upper Trapezius (Prihati, 2014).

Sindrom myofascial adalah nyeri otot yang ditandai dengan timbulnya satu atau beberapa titik picu yang disebut dengan trigger points. Kondisi ini sering ditemukan pada semua orang dengan keadaan inaktivitas akibat posisi beraktivitas dengan posisi yang tidak ergonomis dalam jangka waktu lama terutama pada area leher khususnya otot Upper Trapezius yang sering ditemukan berkontraksi berlebihan mempertahankan postur kepala yang cenderung jatuh ke depan karena kekuatan gravitasi atau berat kepala itu sendiri. Kontraksi berlebih memicu timbulnya trigger points pada taut band yang menimbulkan nyeri sindrom myofascial sehingga akan berdampak pada keterbatasan gerak leher ${ }^{3}$.

Penanganan fisioterapi yang dapat diberikan untuk sindrom myofascial dapat berupa terapi modalitas seperti Ultrasound yang akan dikombinasikan dengan terapi manual seperti INIT dan Contract Relax Stretching. Pemberian terapi tersebut aman diaplikasikan dan bertujuan untuk mengurangi perlengketan di fascia dan aman untuk diaplikasikan dan mampu meningkatkan fleksibilitas otot leher sehingga berdampak pada peningkatan lingkup gerak sendi.

Kombinasi Ultrasound dengan Contract Relax Stretching akan memberikan dampak dalam mempercepat penyembuhan jaringan, pelepasan adhesi, menurunkan nyeri, meningkatkan elastisitas dan fleksibilitas jaringan, elongasi otot secara maksimal serta meningkatkan lingkup gerak sendi leher. Disamping itu, kombinasi INIT dengan Ultrasound merupakan suatu kombinasi terapi baru yang memberi dampak lebih positif dalam menangani sindrom myofascial otot Upper Trapeziuskarena bekerja dengan langsung pada trigger point, mempercepat proses perbaikan jaringan dengan merangsang proses inflamasi fisiologis, melepas adhesi, mengurangi nyeri, menurunkan spasme, meningkatkan fleksibilitas otot, meningkatkan lingkup gerak sendi leher. Kombinasi ini masih sangat sedikit yang mengaplikasikan serta masih sedikit penelitian mengenai keefektifannya jika dibandingkan dengan teknik Contract Relax Stretching dalam meningkatkan lingkup gerak sendi leher.

Tujuan umum dari penelitian ini adalah untuk mengetahui pemberian Integrated Neuromuscular Inhibition Technique dengan Ultrasound lebih efektif meningkatkan lingkup gerak sendi leher daripada Contract Relax Stretching dengan Ultrasound pada sindrom myofascial otot Upper Trapezius.

\section{MATERI DAN METODE}

Penelitian ini adalah penelitian eksperimental yang bersifat Pre Test-Post Test control group design. Jumlah sampel 24 yang dibagi menjadidari 12 sampel pada tiap kelompok perlakuan. Penelitian dilakukan pada Praktek Fisioterapi Swasta di Denpasar selama 3 bulan terhitung mulai awal bulan Januari sampai awal bulan Maret 2017. Intervensi terapi tiap responden dilakukan sebanyak enam kali selama 2 minggu.

Populasi dalam penelitian ini adalah seluruh pasien terindikasi sindrom myofascial otot Upper Trapezius yang datang untuk mendapatkan intervensi fisioterapi ke praktek fisioterapi swasta di Denpasar dalam periode bulan Januari sampai Maret 2017. Sampel penelitian sebanyak 24 orang dipilih dari populasi yang memenuhi kriteria inklusi dan eksklusi yang dibagi kedalam dua kelompok perlakuan secara random dengan teknik permutasi blok, dimana kelompok 1 akan diberikan intervensi INIT dengan ultrasound dan kelompok 2 diberikan contract relax stretching dengan ultrasound.

Intervensi Ultrasound diberika dengan intensitas $0,3-0,8 \mathrm{~W} / \mathrm{cm} 2$, frekwensi $3 \mathrm{MHz}$, ERA $5 \mathrm{~cm}^{2}$ waktu disesuaikan dengan rumus durasi intervensi oleh Watson, dilakukan sebelum dilakukan sebelum intervensi manual. Contract-relax-Stretching diberikan sebanyak 6 kali dimana dilakukan kontraksi otot secara isometrik selama tujuh detik diikuti rileksasi, selanjutnya dilakukan stretching selama tujuh detik, diulangi enam kali dengan posisi otot yang memanjang. Dosis INIT adalah dilakukan sebanyak tiga kali pengulangan. Masing-masing sampel dilakukan pengukuran disabilitas leher dengan alat ukur neck disability index (NDI) yang diikuti pengukuran lingkup gerak sendi leher lateral fleksi kontralateral dengan goniometer sebelum dan sesudah perlakuan.

\section{HASIL PENELITIAN}

Tabel 1. Karakteristik Sampel

\begin{tabular}{lcc}
\hline Karakteristik & Kel 1 & Kel 2 \\
\hline Umur (Th) & $39,58 \pm 3,370$ & $40,00 \pm 2,730$ \\
\hline Jenis kelamin: & & \\
\hline Laki- laki & $4(33,3)$ & $3(25)$ \\
\hline Perempuan & $8(67,7)$ & $9(75)$ \\
\hline Pekerjaan: & & \\
\hline Tenaga administrasi & 3 & 3 \\
\hline IRT & 2 & 1 \\
\hline Pembuat Banten & 1 & 2 \\
\hline Pegawai Bank & 2 & 3 \\
\hline Front Office & 1 & 1 \\
\hline Dosen & 2 & 1 \\
\hline Penjahit & 1 & 1 \\
\hline
\end{tabular}


Tabel 2. Uji Normalitas

\begin{tabular}{cccc}
\hline \multirow{2}{*}{ Kelompok Data } & \multicolumn{2}{c}{ Shapiro Wilk-Test } & \\
\cline { 2 - 3 } & $\begin{array}{c}\text { Kel 1 } \\
(p)\end{array}$ & $\begin{array}{c}\text { Kel 2 } \\
(p)\end{array}$ & Levene's Test $(p)$ \\
\hline LGS Sebelum Perlakuan & 0,418 & 0,160 & 0,158 \\
\hline LGS Sesudah Perlakuan & 0,223 & 0,259 & 0,630 \\
\hline
\end{tabular}

Data LGS sebelum perlakuan dan sesudah perlakuan pada kedua kelompok perlakuan berdistribusi normal ( $p$ $>0,05)$. Disamping itu varian LGS sebelum dan setelah perlakuan kedua kelompok adalah homogen $(p>0,05)$.

\begin{tabular}{cccccc}
\multicolumn{7}{c}{ Tabel 3. Uji Hipotesis } \\
\hline & Kel & Pre & Post & Selisih & \\
\hline LGS & 1 & $38,08 \pm 1,78$ & $43,17 \pm 1,46$ & $5,083 \pm 1,084$ & $\mathrm{p}^{\mathrm{a}}<0,001$ \\
\cline { 2 - 6 } (derajat) & 2 & $37,67 \pm 0,88$ & $41,00 \pm 1,34$ & $3,333 \pm 0,778$ & $\mathrm{p}^{\mathrm{a}}<0,001$ \\
\cline { 2 - 6 } & $\mathrm{p}^{\mathrm{b}}=0,476$ & $\mathrm{p}^{\mathrm{b}}<0,001$ & $\mathrm{p}^{\mathrm{b}}<0,001$ & \\
\cline { 2 - 6 } a. dengan Paired T-Test & & & &
\end{tabular}

b. dengan Independent T-Test

Hasil perhitungan uji hipotesis berpasangan dalam kelompok yang didapatkan nilai $p$ untuk derajat lingkup gerak sendi leher (LGS) yaitu $<0,001$ yang menyatakan bahwa ada perbedaan yang bermakna sebelum dan sesudah pada kedua kombinasi intervensi pada sindrom myofascial otot upper trapezius $(p<0,05)$.

Berdasarkan Tabel 3, menunjukkan nilai p kedua variabel selisih dan setelah perlakuan antar kelompok adalah $<0,001$. Hasil tersebut menyatakan terdapat perbedaan yang bermakna pada hasil penerapan intervensi kedua kelompok $(\mathrm{p}<0,05)$. Disimpulkan kombinasi integrated neuromuscular inhibition technique dengan Ultrasound lebih meningkatkan lingkup gerak sendi dibandingkan dengan contract relax stretching dengan Ultrasound.

\section{PEMBAHASAN \\ Karakteristik Subjek}

Karakteristik subjek penelitian memiliki rerata umur 39,58 tahun pada Kelompok I dan memiliki rerata umur 40 tahun pada Kelompok II. Kelompok perlakuan 1 subjek berjenis kelamin laki-laki sebanyak 4 orang $(33,3 \%)$ dan perempuan sebanyak 8 orang $(67,7 \%)$, sedangkan pada kelompok perlakuan 2 subjek berjenis kelamin laki-laki sebanyak 4 orang (25\%) dan perempuan sebanyak 9 orang (75\%).Data tersebut menunjukkan bahwa sampel dengan jenis kelamin perempuan lebih banyak dibandingkan dengan sampel laki-laki.

Aktifitas sehari-hari sampel terdiri dari tenaga administrasi, sesorang yang beraktivitas dengan posisi duduk dan menunduk dalam jangka waktu yang lama menyebabkan otot bekerja secara statis dan cenderung mengalami ketegangan otot. Pekerjaan pegawai bank juga dapat menimbulkan ketegangan pada otot-otot leher sebagai akibat otot-otot leher terlalu lama dalam posisi statik. lbu rumah tangga (IRT) sering melakukan aktivitas yang memungkinkan statis pada otot-otot leher. Pembuat banten, dosen, front office, dan penjahit sering duduk dan menunduk dalam waktu yang lama kepala sehingga otot-otot leher cenderung terjadi ketegangan.

\section{Penurunan Disabiltas Leher pada Intervensi Kombinasi Contract Relax Stretching dengan Ultrasound}

Pada pengujian kelompok dengan intervensi contract relax stretching dengan ultrasound dengan menggunakan uji beda paired sample t-test didapatkan $p<0,001(p<0,05)$ yang berarti ada perbedaan yang bermakna sebelum dan sesudah intervensi. Hasil penelitian telah membuktikan bahwa contract relax stretching dengan ultrasound dapat meningkatkan rerata lingkup gerak sendi leher dimana sebelum perlakuan adalah $37,67^{\circ}$ menjadi $41,00^{\circ}$ setelah perlakuan. Hal tersebut menunjukkan bahwa terdapat penurunan disabilitas leher pada perlakuan 2 sebesar $56,82 \%$ didukung dengan peningkatan lingkup gerak sendi leher sebesar $14,53 \%$. Hal ini terjadi karena efek terapi ultrasound terhadap jaringan otot dan system saraf perifer sehingga terjadi relaksasi dan penurunan nyeri pada otot. Efek terhadap sel otot dapat meningkatkan metabolisme dan kontraktil otot ${ }^{4}$. Pengaruh ultrasound terhadap jaringan ikat otot meningkatkan elastisitas, meningkatkan protein matrix dan meningkatkan volume cairan didalam matrix. Selain itu juga dapat meningkatkan tensilestrength, collagen serta meningkatkan sel fibroblast5.

Hal tersebut sesuai dengan teori yang dikemukakan oleh Watson mengenai Ultrasound yang mampu meningkatkan kemampuan alami tubuh untuk menstimulasi proses penyembuhan jaringan. Pengaruh mekanik tersebut juga dengan terstimulasinya saraf polimedal dan akan dihantarkan ke ganglion dorsalis sehingga memicu produksi " $P$ subtance" untuk selanjutnya terjadi inflamasi sekunder atau dikenal "neurogenic inflammation". Namun dengan terangsangnya " $P$ " substance tersebut mengakibatkan proses induksi proliferasi akan lebih terpacu sehingga mempercepat terjadinya penyembuhan jaringan ${ }^{6}$.

Problem disabilitas leher umumnya ditemukan oleh peneliti pada setiap sampel.Rasa nyeri umumnya dirasakan pada saat beraktivitas disertai rasa pusing. Berdasarkan pengamatan dan penulusuran peneliti dari hasil pemeriksaan menunjukkan bahwa problem nyeri umumnya disebabkan oleh muscle spasm atau muscle tightness pada otot-otot leher upper trapezius.

Hasil penelitian ini turut membuktikan bahwa contract relax stretching juga sangat diperlukan sebagai terapi pada sindrom myofascial karena dapat mengurangi spasme difasilitasi oleh reverse innervation pada metode intervensi ini. Kontraksi maksimalakan berkontribusi dalam menggerakkan stretch reseptor dari spindel otot untuk segera menyesuaikan panjang otot maksimal. Pada kontraksi isometrik akan terjadi penurunan stroke volume jantung, penekanan diafragma pada organ dalam dan pembuluh darah yang ada di dalamnya sehingga menekan darah agar keluar dari organ dalam. Saat dilakukan kontraksi isometrik selama 6 detik yang diikuti dengan inspirasi maksimal, motor unit maksimal yang ada pada seluruh otot akan teraktivasi. Kontraksi maksimal ini juga akan memberi rangsang 
golgi tendon organ kepada pusat inhibisi di posterior horn cell medula spinalis untuk menghentikan aktifitas alpha motor neuron sehingga akan memicu relaksasi otot maksimal dan berdampak pada penurunan tonus otot dan spasme berkurang.

Penelitian sebelumnya membuktikan bahwa contract relax stretching efektif dalam menurunkan disabilitas leher diakibatkan peningkatan fleksibilitas otot. Fleksibilitas sering kali dijelaskan sebagai kemampuan struktur atau segmen tubuh untuk bergerak atau digerakkan untuk memungkinkan terjadinya lingkup gerak sendi untuk aktivitas fungsional. Fleksibilitas dan lingkup gerak sendi yang memadai harus didukung oleh penurunan nyeri untuk menurunkan gangguan saat beraktivitas dan memungkinkan individu untuk bergerak secara fungsional ${ }^{7}$.

Stretching atau peregangan maksimal yang diperoleh dari relaksasi yang diikuti ekspirasi maksimal akan mempermudah dalam memperoleh pelemasan otot. Kontraksi isometrik kemudian akan diikuti peregangan secara bersamaan ketika relaksasi dan ekspirasi maksimal yang akan memperpanjang struktur fascia dan keadaan otot yang relaks membantu memicu elongasi maksimal pada saat stretching dilakukan sehingga lingkup gerak sendi leher meningkat.

Hal tersebut didukung oleh penelitian Case Report menunjukkan bahwa intervensi Contract Relax Stretching of Tissue Mobilization pasca operasi memberikan manfaat yang besar bagi pasien dimana terjadi peningkatan mobilitas fungsional cervical kesegala arah antara $7^{\circ}-20^{\circ} .8$

Dalam bukunya yang berjudul Stretching Therapy yang dituliskan Ylinen menyatakan dalam berbagai tulisan para ahli, menyatakan stretching sudah dikenal sebagai metode untuk terapi pada sindrom myofascial. Dengan stretching maka otot akan dilatih untuk memanjang yang akan mempengaruhi sarcomer dan fascia akan mengurangi derajat overlapping antara thick dan thin myofilamen dalam sarcomer sebuah taut band otot yang mengandung trigger points didalamnya. Pengurangan overlapping antara dua myofilamen, mempenkomponen elastin (aktin dan myosin) dalam sarkomer dan tegangan dalam otot meningkat dengan tajam, sarkomer memanjang dan apabila dilakukan berulang maka otot beradaptasi dan hal ini hanya bertahan sementara untuk mendapatkan panjang otot yang diinginkan. Pemanjangan otot akan mengakibatkan pemanjangan serabut serta komponen di dalamnya Sarkomer dan fascia dalam myofibril otot memanjang akibat teregang sehingga berdampak mengurangi derajat overlapping antara thick dan thin myofilamen dalam sarkomer sebuah taut band otot yang di dalamnya mengandung titik picu yang disebut trigger points sehingga menimbulkan elongasi atau ekstensibilitas jaringan serta meningkatkan fleksibilitas serta lingkup gerak sendi leher.

\section{Pemberian Integrated Neuromuscular Inhibition Technique dengan Ultrasound Lebih Efektif Menurunkan Disabilitas Leher daripada Contract Relax Stretching dengan Ultrasound}

Dalam penelitian ini ditemukan peningkatan lingkup gerak sendi leher sebesar 17,93\%, pada kelompok yang diberi intervensi integrated neuromuscular inhibition technique dengan ultrasound, sedangkan pada kelompok yang diberi intervensi contract relax stretching dengan ultrasound peningkatan lingkup gerak sendi leher sebesar $14,53 \%$.

Berdasarkan data tersebut bisa disimpulkan bahwa intervensi integrated neuromuscular inhibition technique dan ultrasound lebih efektif Ultrasound dibandingkan dengan contract relax stretching dengan Ultrasound dalam peningkatan lingkup gerak sendi leher pada sindrom myofascial otot upper trapezius(p>0,001).

Pemberian modalitas ultrasound menimbulkan iritasi jaringan yang menyebabkan reaksi fisiologis sebagai efek ultrasound. Efek terapi ultrasound terhadap jaringan otot dan system saraf perifer sehingga terjadi relaksasi dan penurunan nyeri pada otot. Efek terhadap sel otot dapat meningkatkan metabolisme dan kontraktil otot ${ }^{4}$.

Pengaruh mekanik tersebut juga mestimulasi saraf polimedal menuju ganglion dorsalis sehingga memicu produksi "P"substanceuntuk selanjutnya terjadi inflamasi sekunder atau dikenal "neurogenic inflammation". Dengan diproduksinya " $P$ " substance tersebut memberi efek induksi proliferasi jaringan akan lebih terpacu sehingga mempercepat terjadinya penyembuhan jaringan ${ }^{6}$.

Sindrom myofascial ditandai dengan adanya trigger point pada taut band yang menyebabkan nyeri otot kronik yang dapat mempengaruhi lingkup gerak sendi serta aktivitas fungsional. Metode yang efektif dalam mengatasi kasus ini adalah intervensi yang mampu melakukan deaktivasi trigger pointdengan cara memperlancar suplai oksigen dan metabolik serta energi kedalam sel dan jaringan otot. Kombinasi INIT dengan Ultrasoundmerupakan suatu kombinasi intervensi yang belakangan ini mulai diterapkan dan tampak memberi dampak lebih positif dalam menangani sindrom myofascial otot Upper Trapeziuskarena bekerja dengan langsung dengan memicu deaktivasi trigger point danmelepas adhesi sehingga lebih efektif dalam dibandingkan Contract Relax Stretching. Kombinasi intervensi ini juga efektif dalam mempercepat proses perbaikan jaringan dengan merangsang proses inflamasi fisiologis, mengurangi nyeri, menurunkan spasme, meningkatkan fleksibilitas otot, meningkatkan lingkup gerak sendi leher.

Hasil penelitan sesuai dengan teori, INIT merupakan intervensi yang efektif dalam mengatasi sindrom myofasciakarena bekerja langsung terhadap trigger point ${ }^{15}$.Berdasarkan penelitian didapatkan bahwa integrated neuromuscular inhibition technique dapat menurunkan disabilitas leher dan peningkatan lingkup gerak sendi leher sesuai dengan hasil penelitian sebelumnya ${ }^{10}$. Pada penelitian tersebut dilaporkan bahwa dengan kompresi pada area jaringan myofascial yang memiliki taut band dan trigger points menimbulkan peningkatan tekanan osmolaritas pada membran sel sehingga mampu mempengaruhi permeabilitas membrane serta meningkatkan tekanan hidrostatik pada pembuluh darah perifer. Ketika tekanan dilepaskan maka akan terjadi limpahan aliran darah pada area trigger point yang dapat mengakibatkan pengeluaran zat-zat sisa iritan berupa sisa metabolisme yang menumpuk pada jaringan myofascial yang akan dibawa kembali melalui proses reabsorbsi dan menimbulkan penurunan iritasi pada nosiseptor sehingga nyeri berkurang.

Kompresi pada area jaringan myofascial yang memiliki taut band dan trigger points,akan merangsangpengeluaran zat-zat sisa iritan berupa sisa metabolisme yang menumpuk pada jaringan myofascial yang akan dibawa kembali melalui proses reabsorbsi dimana akan dibawa oleh aliran darah. Penyerapan zat-zat iritan 
penyebab nyeri tersebut akan berdampak pada penurunan allodynia dan hiperalgesia pada system saraf. Pengaplikasian tekanan yang dalam, akan membuat darah pada jaringan yang terhalang oleh triggerpoint akan tersebar ke area lain disekitarnya hingga penekanan selesai dilakukan. Apabila teknik ini diulang beberapa kali, maka akan menimbulkan mekanisme "irrigation pump" lokal secara signifikan yang akan meningkatkan aliran darah ke area iskemik yang terdapat trigger point, sehingga kebutuhan akan metabolik, oksigen serta energi akan tercukupi dan terserap dengan baik setelah meningkatnya permeabilitas membran dan tekanan hidrostatik pembuluh darah sehingga trigger point akan terdeaktivasi dan nyeri berkurang serta allodynia dan hiperalgesiadapat dicegah ${ }^{11}$.

Hasil penelitian mengenai efektivitas INIT pada myofascial trigger point otot upper trapezius, teknik ini dapat memulihkan spasme pada otot melalui mekanisme spinal refleks dengan memberikan inhibisi transmisi stimulasi nyeri pada substansia gelatinosa. Dengan pemulihan spasme maka diharapkan viscous cycle dapat diputuskan sehingga timbulnya nyeri dapat dihambat ${ }^{12}$.

Hasil penelitian tersebut relevan dengan teori dimana saat otot Upper Trapezius yang spasme serta mengalami disfungsi secara pasif kemudian akan digerakkan ke posisi yang nyaman dimana posisi ini otot memendek dan diberikan tekanan pada muscle spindle akan memicu relaksasi otot ${ }^{12}$. Hal tersebut dikarenakan musclespindle terangsang untuk memberi sinyal dengan benar secara langsung untuk mengatur ulang gamma motor neuron untuk menghentikan informasi kontraksi kepada otot sehingga otot menjadi rileks. Otot yang rileks akan mengakibatkan tonus otot menurun sehingga spasme berkurang dan otot kembali ke posisi yang normal secara $\operatorname{spontan}^{13}$.

Penelitian relevan sebelumnya menyatakan INIT dapat mencegah muscle fatigue dan meningkatkan fleksibilitas serta lingkup gerak sendi leher sehingga dapat menurunkan disabilitras leher pada sindrom myofascial upper trapezius ${ }^{10}$.Fleksibilitas sering kali dijelaskan sebagai kemampuan struktur atau segmen tubuh untuk bergerak atau digerakkan untuk memungkinkan terjadinya lingkup gerak sendi untuk aktivitas fungsional.Fleksibilitas dan lingkup gerak sendi yang memadai untuk menurunkan gangguan saat beraktivitas dan memungkinkan individu untuk bergerak secara fungsional' ${ }^{14}$.

Pemberian tahanan isometrik muscle energy technique menggunakan resisten dengan gaya minimal, dimana hanya beberapa serabut otot yang aktif sedangkan serabut lain terinhibisi. Selama rileksasi otot yang memendek, diregangkan secara ringan dengan menghindari stretch reflex sehingga menimbulkan efek analgesia dan otot menjadi lebih rileks. Gaya yang digunakan sebesar $20-30 \%$, akan menimbulkan recruitment pada serabut otot phasic daripada serabut otot tonik sehingga tercapai pengaruh stretching otot.Otot diregangkan setelah diberikan resistensi isometrik akan mengalami pemanjangan yang mempengaruhi sarkomer dan fascia dalam myofibril otot untuk memanjang. Pemanjangan sarkomer dan fascia akan mengurangi derajat overlapping antara thick and thin myofilamen dalam sarkomer sebuah taut band otot yang mengandung trigger point yangakan mempengaruhi pelebaran pembuluh kapiler otot sehingga sirkulasi darah akan lancar, mengurangi penumpukan sampah metabolisme, meningkatkan nutrisi dan oksigen pada sel otot dan mencegah adanya muscle fatique.Ketika kebutuhan oksigen untuk pembakaran terpenuhi, kalsium terpompa kembali ke reticulum sarkoplasmik menyebabkan pelepasan asetil kolin oleh reticulum sarkoplasmik akan terhenti yang berakhir dengan normalisasi kadar asetilkolin pada motor endplate sehingga otot mencapai relaksasi optimal serta mampu mencapai berpengaruh terhadap peningkatan lingkup gerak pada leher ${ }^{15}$.

Disamping itu menurut buku mengenai manual therapy yang disusun oleh Chaitow disebutkan bahwa resistensi isometrik yang diberikan saat akhir intervensi INITmampu mengurangi nyeri dengan mempengaruhi golgi tendon organ otot yang terletak di tendon berdekatan dengan serabut saraf. Ketika tegangaan meluas ke seluruh serabut saraf maka golgi tendon organ akan melaju menimbulkan relaksasi serta fleksibilitas pada otot ${ }^{15}$. Pengurangan nyeri dan spasme otot disertai dengan peningkatan fleksibilitas otot akan meningkatkan lingkup gerak sendi pada leher.

Berdasarkan mekanisme intervensi diatas dinyatakan bahwa INIT merupakan intervensi fisioterapi yang lebih efektif daripada contract relax stretching dengan ultrasound dalam menurunkan disabilitas leher akibat sindrom myofasciakarena intervensi tersebut memiliki sasaran dalam deaktivasi trigger pointserta melepas adhesi. Hal tersebut dikarenakan sindrom myofascialmuncul akibat dari aktivasi trigger pointpada taut band otot akibat dari adhesi jaringan myofascial sehingga diperlukan intervensi yang langsung menangani pada trigger point.

\section{SIMPULAN}

Berdasarkan analisis penelitian yang telah dilakukan dan pembahasan dapat disimpulkan bahwa pada kasus sindrom myofascial otot Upper Trapezius: 1) Intervesi Contract Relax Stretching dengan Ultrasound dapat meningkatkan lingkup gerak sendi pada leher; 2) Intervensi Integrated Neuromuscular Inhibition Technique dengan Ultrasound dapat meningkatkan lingkup gerak sendi pada leher pada penderita.; 3) Integrated Neuromuscular Inhibition Technique dengan Ultrasound lebih memiliki efek dibandingkan Contract Relax Stretching dengan Ultrasound dalam meningkatkan lingkup gerak sendi pada leher pada penderita.

\section{DAFTAR PUSTAKA}

1. Samara, D. Nyeri musculoskeletal pada leher pekerja dengan posisi pekerjaan yang statis. Universa Medicina 200 7; 26: 137-142.

2. Degaldo, E.V., Romero, J.C. \& Escoda, C.G., 2009. Myofascial Pain Syndrome Associated with Trigger Points: A I iterature review. (I): Epidemiology, Clinical Treatment and Etiopathogeny. Med Oral Patol Oral Cir Bucal, 14, pp.49 4-98.

3. Bron, C. \& Dommerholt, J.D., 2012. Etiology of Myofascial Trigger Point. Current Pain and Headcahe Reports, (16 ), pp.439-444.

4. Micholvitz, S.L., Bellew, J.W., \& Nolan Jr, T.P. 2012. Modalities for Therapeutic Intervention. $5^{\text {th }}$ ed. Philadelpia: F. A.Davis Company, pp.85-115. 
5. Bahrens, et al. 2006. The Potential Of A New Stable Ultrasound Contrast Agent For Site-Specific Targeting. An In Vitro Experiment. Ultrasound in medicine \& biology 32.10, pp: 1473-1478.

6. Prentice, W. 2011. Therapeutic modalities in rehabilitation. McGraw Hill Professional.

7. Ylinen, J., Kautiainen, H., Wirén, K., \& Häkkinen, A. (2007). Stretching exercises vs manual therapy in treatment of chronic neck pain: a randomized, controlled cross-over trial. Journal of Rehabilitation Medicine, 39(2), 126-132.

8. Gugliotti, M. 2011. The use of mobilization, muscle energy technique, and soft tissue mobilization following a modi fied radical neck dissection of a patient with head and neck cancer. Rehabilitation Oncology, 29(1), 3-8.

9. Asri, Muh, and Susy Purnawati. 2016. Contract Relax Stretching Dan Ultrasound Therapy Lebih Efektif Menurunk an Nyeri Dibandingkan Ischemic Compression Tehnique Dan Ultrasound Therapy Pada Pasien Tension Headach e. Sport and Fitness Journal 4.2, pp: 12-20

10. Nagrale, A: Glyn, P; Joshi, A. 2010. The efficacy Of INIT On Upper Trapezius Trigger Point in neck Pain. Escorts Physical TherapyCollage.USA.Journal of Manual and Manipulative Therapy, pp. 37-44

11. Nayak, Prajna P. 2013. A study to find out the efficacy of INIT (Integrated Neuromuscular Inhibitation Technique) with therapeutic ultrasound Vs INIT with placebo ultrasound in the treatment of acute myofascial trigger point upper trapezius. The Oxford College of Physiotherapy. Banglore

12. Cagnie, B, et al., 2015. Evidence for the use of ischemic compression and dry needling in the management of trig ger points of the upper trapezius in patients with neck pain: a systematic review. American Journal of Physical Me dicine \& Rehabilitation,94(7), pp.573-583.

13. Widodo, A., 2011. Penambahan Ischemic Pressure, Sustained Stretching,dan Koreksi Posture Bermanfaat pada I ntevensi Kasus Myofascial Trigger Point Syndrome Otot Trapezius bagian atas. Thesis. Denpasar: Universitas Ud ayana, pp.10-15.

14. Shah, Salvi, and Akta Bhalara. 2012. Myofascial Release. Inter J Health Sci Res 2.2, pp: 69-77.

15. Chaitow, L., 2013. Muscle Energy Technique 4 ${ }^{\text {th }}$ Edition. Londom: Churchill Livingstone Elsevier, pp.303-310

16. Kisner, C. \& Colby, L.A., 2012. Therapeutic Exercise Foundations and Techniques. 6th ed. USA: F.A.Davis Comp any, pp.65-110. 